\title{
What Price the Moral High Ground?
}

\author{
ROBERT H. FRANK* \\ Cornell University \\ Ithaca, New York
}

\section{Introduction}

Are people fundamentally selfish? In textbook accounts of rational choice, economists generally take an agnostic position on this question: a person's tastes are her own business, and rationality requires merely that she act efficiently in pursuit of whatever preferences she happens to hold. This approach affords obvious flexibility. A person's anonymous gift to charity, for example, can be readily explained as the consequence of a taste for helping others.

But this flexibility comes at the expense of what George Stigler might have called the "crankcase oil" problem. If we see a person drink the used crankcase oil from his car, and he then writhes in agony and dies, we can assert that he must have really liked crankcase oil. (Why else would he have drunk it?) Virtually any behavior, no matter how bizarre, can be "explained" after the fact by simply assuming a taste for it.

With this difficulty in mind, many economists assume-implicitly or explicitly-that people are essentially self-interested. Thus, in Gordon Tullock's words, "the average human being is about 95 percent selfish in the narrow sense of the term" $[21 ; 12,12]$. This approach has generated many powerful insights into human behavior. It explains, for example, why car pools form in the wake of increases in gasoline prices and why the members of "service" organizations are more likely to be real estate salespersons, dentists, chiropractors, insurance agents, and others with something to sell than to be postal employees or airline pilots.

But the assumption of selfishness is not without drawbacks of its own. The most apparent is that, for every behavior that is consistent with this assumption, there seems to be another that contradicts it. Travelers on interstate highways leave tips for waitresses they will never see again. People vote in presidential elections and they walk away from profitable transactions whose terms they believe to be "unfair." Soldiers throw their bodies atop live grenades to save the lives of their comrades. In these and countless other ways, people do not seem to be maximizing utility functions of the egoistic sort.

A second difficulty with the selfishness assumption is that our models of human behavior appear to mold the behavior of both the modelers themselves and those they teach. Thus, Gilovich, Regan and I found evidence that people with extensive training in economics are less likely than

*Financial support for this research was provided by the Alfred P. Sloan and Russell Sage Foundations. I thank Todd Zielinski, Caglar Ozden, and Sendhil Mullainathan for able research assistance. I also acknowledge helpful discussions with Femida Handy, whose thoughtful paper [9] prompted me to complete the work I had begun several years earlier on this study. And of course I was deeply honored by John Siegfried's invitation to present my findings as the Distinguished Guest Lecturer to the 1995 annual meetings of the Southern Economic Association. 
others to cooperate in social dilemmas, and that this difference is at least in part a consequence of their training. ${ }^{1}$

In the end, the importance of other-regarding preferences must be assessed empirically. In this paper I employ the time-honored tradition of looking to the labor market for evidence on preferences. Just as wage differentials across jobs that carry different levels of risk tell us something about worker's preferences regarding safety, I will argue that wage differentials in other settings shed light on the strength of people's concerns about others. Indeed, I will argue that, for a large sample of college graduates, even crude measures of moral satisfaction on the job do more to explain wage differences than do the human capital variables traditionally used for this purpose. An second intriguing finding is that measures of moral satisfaction also seem to eliminate unexplained wage differentials between men and women. Women are more likely than men to choose jobs that afford high measures of moral satisfaction, but men who choose such jobs pay precisely the same wage penalty that women do.

\section{Evidence from Existing Studies}

My survey of the existing literature uncovered several sources of evidence-mostly indirect or qualitative - in favor of the hypothesis that moral concerns figure prominently in career decisions. One early study presented the results of a national cross-section survey of the factors that influence the career choices of college students [17]. Participants in the survey were asked to "consider to what extent a job or career would have to satisfy each of [the following] requirements before you would consider it IDEAL" $[17,12]$.

1. Provide an opportunity to use my special abilities or aptitudes.

2. Provide me with a chance to earn a great deal of money.

3. Give me a chance to exercise leadership.

4. Give me social status and prestige.

5. Give me an opportunity to work with people rather than things.

6. Enable me to look forward to a stable, secure future.

7. Leave me relatively free of supervision by others.

8. Permit me to be creative and original.

9. Provide me with adventure.

10. Give me an opportunity to be helpful to others.

The most highly ranked of these ten career values was "provide an opportunity to use my special abilities or aptitudes," which was rated as "highly important" by 78 percent of respondents. Next came "enable me to look forward to a stable, secure future" (61 percent), followed by "permit me to be creative and original" (48 percent). The career value of special interest for present purposes - "give me an opportunity to be helpful to others" - was ranked fourth on the list of ten. It was rated as highly important by 43 percent of respondents, and another 44 percent called it of "medium importance." Only 13 percent said it was of "little or no importance, irrelevant, or distasteful." Taken at face value, these responses suggest that an overwhelming majority of college students would be willing to trade pay or other desired working conditions in exchange

1. See Frank, Gilovich, and Regan [6] and Frank [5, ch. 12]. For a challenge to our claim, and our rejoinder, see Yezer, Goldfarb, and Poppen [24]; and Frank, Gilovich, and Regan [7]. 
for additional opportunities to help others on the job. These responses, of course, tell us nothing about the rate at which students would be willing to make such tradeoffs.

A second study asked business executives about the effect of their firm's ethical conduct on its profitability [2]. Several respondents said that their firm's ethical posture affected its ability to recruit in the labor market. For instance, an executive of a retail firm whose founder had created a strong reputation for ethical dealing offered this description $[2,105]$.

The top executive has created the kind of environment he wants; it is calculated, but it is good and promotes good ethics. Furthermore, our customers ... like the courteous and kind treatment given by our sales people. Now we get sales ladies from the same pool of personnel that other retail stores in the area get their help, but our help is more courteous because of the reputation which the president has established. New sales ladies catch on; their better side shows through in their work And we don't pay any more than other stores around here either-probably we pay a little less. (Emphasis added.)

Other executives reported that a firm's reputation for unethical dealings-even when based on behavior in the distant past-made recruiting difficult. As one railroad executive put it, "We still have people around who remember the old robber barons ... These men were very unethical at the time and the result of their operation still hurts us today" $[2,107]$. The same sentiment was echoed by an electrical industry executive in reference to that industry's highly publicized pricefixing scandal: "The students really quiz us since the indictments. They want to know whether collusion has stopped and what the company policy is" $[2,107]$. Again, while such responses are suggestive, they tell us little about the rate at which workers are willing to trade pay for a working environment that emphasizes social responsibility.

In a recent study, Scott Vitell and D. L. Davis [22] surveyed managers in the management information systems (MIS) field to discover the extent to which the ethical posture of their employers was related to job satisfaction. Job satisfaction was assessed using the Managerial Job Satisfaction Questionnaire developed by Cellucci and De Vries [4]. The ethical posture of the respondents' employers was measured by the extent to which respondents agreed with the statement, "MIS managers in my company often engage in behavior that I consider to be unethical." The correlation coefficient between responses to this statement and the index of job satisfaction was -0.26 , which is statistically significant at the 0.05 level.

As in the case of the other studies reported, the Vitell and Davis finding suggests a willingness on the part of employees to trade pay and other valued working conditions in exchange for a more ethical working environment. But here again the authors have no basis upon which to estimate the rate at which such job characteristics might be exchanged. This issue is the focus of the remaining sections of this paper.

\section{The Theoretical Framework for the Current Study}

Jobs differ in countless dimensions, one of which is the degree to which the worker contributes to the well-being of others. Consider two jobs identical along all dimensions except this one. (For example, one job might involve writing advertising copy for a product known to cause serious health problems, while the other involves writing advertising copy for the United Way.) If people derive satisfaction from engaging in altruistic behavior, it follows that if the wages in these two jobs were the same, there would be an excess supply of applicants to the second job, a shortage of applicants to the first. In equilibrium, we would therefore expect a compensating wage premium 


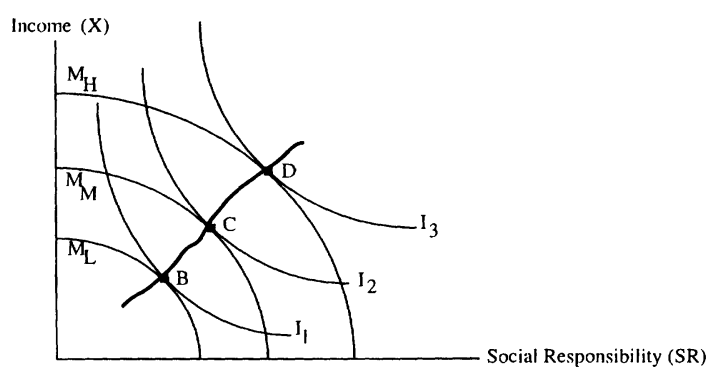

Figure 1. Equilibrium Quantities of Monetary Income and Social Responsibility

for the less altruistic job. A job applicant can occupy the moral high ground if he wants to, but only by accepting lower wages. This wage differential serves as a measure of the strength of the particular nonegoistic motive involved.

More formally, suppose we modify the traditional utility function to be of the form

$$
U=U(X, S R)
$$

where $X$ is monetary income and $S R$ the degree of social responsibility attributed to the job. In Figure 1 , the curves $I_{1}, I_{2}$, and $I_{3}$ are part of the indifference map to which this utility function gives rise. Let $M$ stand for ability, the endowment with which agents purchase both monetary income and social approval. In Figure 1, the curves $M_{L}, M_{M}$, and $M_{H}$ represent the opportunity sets for persons of low, medium and high ability, respectively.

$B, C$, and $D$ denote the optimal bundles along each of these opportunity sets. The locus that includes $B, C$, and $D$ is the income-expansion path, shown as upward sloping in Figure 1 on the assumption that social responsibility is a normal good.

If social responsibility is indeed a normal good, we expect a positive correlation between $X$ and $S R$ in cross-section data, even though each individual's opportunity set is downward sloping. (Analogously, individuals with low ability typically end up with jobs that offer both low pay and unpleasant working conditions.)

The task is to estimate the shape of the opportunity set for a given level of ability. Its slope at any point may be interpreted as the price of the moral high ground at that point. The two main technical difficulties that must be confronted are (1) to control for ability and other working conditions across jobs; and (2) to devise an operational measure of social responsibility.

The ideal way to control for ability is to work with longitudinal data on job switchers. When a person leaves a job with a low social responsibility rating in favor of an otherwise similar job with a higher rating, we can be sure that an ability difference does not lie behind the observed change in wages. The difficulty with existing longitudinal data sets, such as the National Longitudinal Survey, is that they do not supply sufficiently detailed employer and job descriptions to facilitate measures of social responsibility.

In cross-section data, the best way to control for ability is to employ standard human capital measures. The difficulty with most readily available cross-section data sets is that the human capital information they provide lacks the rich detail one would ideally like to have for this kind of application. I was therefore fortunate to gain access to a cross-section data set that promises to be much better than most in this regard. In the next section, I describe the findings of my analysis of these data. 
Table I. Abbreviated Earnings Regression

\begin{tabular}{|c|c|c|c|c|}
\hline Variable & Coefficient & s.e. of Coeff. & $t$-ratio & \\
\hline Constant & 9.71074 & 0.0445 & 218 & \\
\hline profit & 0.205506 & 0.0449 & 4.58 & \\
\hline government & 0.0000 & - & - & \\
\hline nonprofit & -0.321129 & 0.0544 & -5.90 & \\
\hline male & 0.110497 & 0.0310 & 3.57 & \\
\hline Source & Sum of Squares & df & Mean Square & $F$-ratio \\
\hline Regression & 31.3892 & 3 & 10.46 & 65.3 \\
\hline Residual & 108.350 & 676 & 0.160281 & \\
\hline
\end{tabular}

Notes:

Dependent variable $=$ natural logarithm of salary

$R^{2}=22.5 \%$

$R^{2}$ (adjusted) $=22.1 \%$

$s=0.4004$ with $680-4=676$ degrees of freedom

\section{Results from the Cornell Employment Survey}

Several years ago, Cornell University's career center completed an employment survey of recent graduates of the university's College of Arts and Sciences. This survey provided information on the current activities of respondents nine months after their graduation from Cornell. For those who were gainfully employed, the survey recorded information on annual salary, job title, and the name and location of employer. Taking special steps to protect the anonymity of respondents, I was able to match the individual survey response forms with the college transcript of each respondent. Thus, unlike standard employment survey data sets, my data make it possible to control for the respondent's degree field as well as a rich variety of other details related to academic performance. And since almost all of these data pertain to first jobs, I have access to almost as much information as did the employers who did the actual hiring.

By examining annual reports and other available records for each employer represented in the survey, I was able to categorize each employer as belonging to either the profit, nonprofit, or government sector of the economy. These categories provide at least a crude measure of the degree of social responsibility associated with respondents' jobs, with employment in the nonprofit sector rated highest, government next, and the for-profit sector last on the social responsibility scale. Before reporting on the results of an attempt to construct a much more detailed measure of employer social responsibility, I first summarize preliminary estimates of wage differences between the profit, nonprofit, and government sectors.

The dependent variable in the abbreviated regression reported in Table I is the natural logarithm of annual salary in 1986 dollars. Control variables in this regression include only the worker's sex and sector of employment-private for-profit, private nonprofit, and government. The coefficients on the sector-of-employment variables are strikingly large. Someone in the private for-profit sector earns almost 21 percent more than a government worker, whereas someone in the private nonprofit sector earns more than 32 percent less than a government worker. For the sample as a whole, males earned almost 14 percent more than females, but this difference shrinks to 11 percent when we control for sector of employment.

The regression reported in Table II expands the list of control variables to include the num- 
Table II. Determinants of Earnings for 1986 and 1987 Cornell University Graduates

\begin{tabular}{|c|c|c|c|c|}
\hline Variable & Coefficient & Standard error & $t$-ratio & \\
\hline Constant & 9.67822 & 0.1267 & 76.4 & \\
\hline profit & 0.133737 & 0.0429 & 3.12 & \\
\hline nonprofit & -0.285866 & 0.0525 & -5.45 & \\
\hline government & 0.000000 & - & - & \\
\hline male & 0.053639 & 0.0301 & 1.78 & \\
\hline math & 0.021743 & 0.0031 & 7.02 & \\
\hline science & -0.001824 & 0.0028 & -0.660 & \\
\hline econ & 0.014775 & 0.0046 & 3.18 & \\
\hline business & 0.036753 & 0.0090 & 4.07 & \\
\hline GPA & -0.019860 & 0.0374 & -0.531 & \\
\hline Source & Sum of Squares & df & Mean Square & $F$-ratio \\
\hline Regression & 44.7167 & 8 & 5.590 & 39.5 \\
\hline Residual & 95.0227 & 671 & 0.141613 & \\
\hline
\end{tabular}

Notes:

Dependent variable $=$ natural logarithm of salary

$R^{2}=32.0 \%$

$R^{2}$ (adjusted) $=31.2 \%$

$s=0.3763$ with $680-9=671$ degrees of freedom

bers of mathematics, science, economics, and business courses taken, and the worker's cumulative grade point average as an undergraduate at Cornell. For present purposes, the independent variables of greatest interest are again those for employment in the profit, nonprofit, and government sectors. But before turning to the performance of these variables, first a brief discussion of the control variables. As the regression coefficients in the Table II indicate, salaries are positively and significantly associated with the number of courses taken in business, economics, and mathematics. Business courses had the largest association, followed by economics and math. Surprisingly, the number of science courses taken was weakly negatively associated with starting salaries, but this effect was not statistically significant at conventional levels. Perhaps even more surprising, grade point average was also weakly negatively associated with starting salaries, but here too the effect was not statistically significant. ${ }^{2}$

These negative science and GPA coefficients almost certainly do not imply that taking an extra science course or having higher grades will actually cause a worker's starting salary to go down. A more plausible account is that people in the sample who took more science courses or earned higher grades were for some other reasons led to choose jobs with slightly lower starting salaries. In support of this interpretation, we observe that sample members who chose jobs in the nonprofit sector had an overall grade point average of 3.14, as compared with 3.09 for those who chose jobs in the for-profit sector. Similarly, those who chose jobs in the nonprofit sector had an average of 1.05 fewer math courses, 2.4 fewer economics courses, and 1.5 fewer business courses - but almost five more science courses - than did those who chose jobs in the for-profit sector. Another possible interpretation, supported by the findings of at least two other studies, is

2. Ashenfelter and Mooney [1] found that academic performance had equally low power explaining earnings differentials among Woodrow Wilson Fellows from Princeton. 
that a significant positive correlation between academic performance and earnings does not show up until several years after graduation $[19 ; 10]$.

Note also in Table II that the inclusion of the curriculum variables causes an additional decline in the sex coefficient. Males now earn only 5.4 percent more than females. This finding lends support to claims that at least part of the observed male-female earnings differential is attributable to differences in the types of courses taken in college.

Employment in the government sector is again the reference category in Table II, which means that the coefficients for the profit and nonprofit variables represent deviations from that category. For example, a person employed by a private for-profit firm earns a salary more than 13 percent larger than she would if she were employed by government. A person working for a nonprofit firm, by contrast, earns almost 29 percent less than she would in a government job. ${ }^{3}$ Thus, even after controlling for sex, curriculum, and academic performance, employees of forprofit firms in our sample earn roughly 59 percent more, on the average, than do employees of nonprofit firms.

By any reasonable standard, the salary gap between for-profit and nonprofit firms in Table II is enormous. Of course, the entire gap is not necessarily attributable to compensating differentials for social responsibility in the nonprofit sector. For example, some of the difference may be the result of unmeasured productivity differences between nonprofit and for-profit workers. But given the relative homogeneity of graduating classes at universities like Cornell, and given our ability to control for curriculum and academic performance, it would be difficult to maintain that unmeasured productivity differences could account for a large share of the nonprofit wage deficit. There is certainly no evidence in these data that nonprofit workers were any less motivated or capable as undergraduate students. As noted earlier, nonprofit employees in our sample had slightly higher grade point averages than did for-profit employees. Nonprofit workers also took an average of almost five more science courses than did for-profit employees.

Another possibility is that dimensions of job satisfaction other than social responsibility may differ systematically between the nonprofit and for-profit sectors. At least some of these differences, however, seem to favor the for-profit sector. For example, the average level of office space and other physical amenities in the workplace is higher in the for-profit than in the nonprofit sector, as are travel allowances and other nonsalary compensation items. Such differences suggest that the true compensation gap between nonprofit and for-profit firms may be even larger than suggested by the results in Table II.

To generate a more precise measure of the compensating wage differential for social responsibility, it is necessary to make finer distinctions between employers than the crude tripartite division considered thus far. Another important step in this effort is to make use of social attitudes regarding the reported occupations of survey respondents. Because my review of the sociological literature revealed only fragmentary usable information on social responsibility ratings by occupational category, and virtually no information on such ratings by category of employer, I found it necessary to devise original surveys to generate this information.

First, I distributed a list of the names of the largest (and hence most easily recognized) employers from the Cornell salary survey to a large class of second-year Cornell MBA students in a business ethics course, and asked each student to rate each of these employers on a 7-point

3. Other studies have also found large wage differentials for non-profit employment. See, for example, Mervis and Hackett [13], Shackett and Trapani [18], and Preston [16]. 
Table III. Social Responsibility Ratings of Selected Occupations

\begin{tabular}{lllc}
\hline Occupation & Rating & Occupation & Rating \\
\hline Stock Broker & -1.44 & Military Officer & 0.49 \\
Salesman & -1.27 & Quality Control Assistant & 0.50 \\
Trader & -1.14 & Reporter & 0.57 \\
Expatriate Tax Specialist & -1.03 & Physicist & 0.60 \\
Leasing Consultant & -0.90 & Librarian & 0.62 \\
Buyer & -0.66 & Emergency Room Registrar & 0.69 \\
Account officer & -0.63 & Park Ranger/Interpreter & 0.72 \\
Marketing Analyst & -0.60 & Geologist & 0.73 \\
Tax Associate & -0.58 & Chemist & 0.87 \\
Advertising Coordinator & -0.57 & Nurses Assistant & 0.87 \\
Risk Analyst & -0.50 & Nanny & 0.92 \\
Publicist & -0.48 & Agro-Forester & 1.14 \\
Credit Analyst & -0.42 & Counselor & 1.18 \\
Appraiser & -0.32 & Family Advocate & 1.21 \\
Accountant & -0.16 & Child Behavior Specialist & 1.53 \\
Mathematician & -0.06 & Environmental Consultant & 1.66 \\
Congressional Intern & 0.01 & Child Care Counselor & 1.78 \\
Legislative Analyst & 0.05 & Community Health Worker & 1.82 \\
Intern & 0.18 & Subs Abuse Prevention & 1.84 \\
Foreign Service Officer & 0.20 & Shelter Coordinator & 1.89 \\
Archaeological Supervisor & 0.34 & Emergency Medical Tech. & 1.98 \\
Engineer & 0.45 & Teacher & 1.98 \\
\hline
\end{tabular}

social responsibility scale. On this scale, 1 represented the least socially responsible employer, 7 the most responsible. Second, I compiled a list of the occupations most frequently reported in the Cornell survey and asked the same group of business ethics students to rate these occupations on a similar 7-point scale.

Because different students applied different standards in their responses on these social responsibility surveys, each student's response for each employer and occupation was recalculated as the difference between her actual numerical response for the item and her mean response for all items in that category. For example, if a student rated the occupation of "teacher" as a 5 on the social responsibility scale, and that student's mean response for all occupations was 3.0 , then the student's rating for teacher was assigned a numerical value of +2.0 . The corresponding ratings for all students were then averaged to generate the overall social attractiveness rating for each occupation and employer category.

The resulting averages for the 141 job titles evaluated ranged from a low of -1.44 ("Stock Broker") to a high of 1.98 ("Teacher"). Selected job titles and their social attractiveness ratings are shown in Table III.

The corresponding average social responsibility ratings for 185 employers ranged from a low of -1.45 (Drexel Burnham Lambert) to a high of 2.24 (Andrus Children's Home). Selected employers and their ratings are shown in Table IV.

There were 134 respondents whose occupational titles were either unavailable or for some other reason were not evaluated in the social responsibility survey. The corresponding figure for employers was 406 .

To allow for threshold effects and other possible nonlinearities, the social responsibility variables were coded as interval dummies and entered into the salary regression described earlier. I 
Table IV. Social Responsibility Ratings for Selected Employers

\begin{tabular}{lllc}
\hline Employer & Rating & Employer & Rating \\
\hline Drexel Burnham Lambert & -1.45 & AT\&T & 0.27 \\
Salomon Brothers & -1.18 & DuPont & 0.33 \\
BBDO & -0.74 & Xerox & 0.45 \\
Covington \& Burling & -0.62 & Hewlett Packard & 0.47 \\
EF Hutton & -0.59 & Carnation Company & 0.49 \\
Cravath, Swaine \& Moore & -0.59 & New American Library & 0.59 \\
New Horizons Motion Picture & -0.47 & McGraw-Hill Inc. & 0.69 \\
Macy's & -0.38 & Hoffman-La Roche & 0.71 \\
Ratner Kessler Realty & -0.35 & The Buffalo News & 0.72 \\
Arthur Andersen \& Co. & -0.30 & US News \& World Report & 0.89 \\
General Dynamics & -0.29 & WW Norton and Co. & 0.97 \\
Metropolitan Life Ins. Co. & -0.16 & Scientific American & 1.05 \\
Holiday Inns Inc. & -0.03 & The Chron. of Higher Ed. & 1.14 \\
Data General Corp. & -0.01 & Bristol-Myers Co. & 1.25 \\
Prudential Insurance & -0.01 & Oncogene Sciences & 1.29 \\
Digital Equipment & 0.016 & New Eng. Jour. of Medicine & 1.67 \\
IBM & 0.09 & Boston City Hospital & 2.13 \\
Aetna Life \& Casualty Co. & 0.13 & Andrus Children Home & 2.24 \\
\hline
\end{tabular}

started with very narrow interval dummies for the two social responsibility measures, and then simplified by adding adjacent intervals together whenever so doing did not significantly reduce the overall explanatory power of the regression. The resulting social responsibility coefficient estimates are reported in Table V.

For both the Occupational Social Responsibility (OSR) and Employer Social Responsibility (ESR) variables, entries in the interval $(-.5, .5)$ were designated as the reference category. Coefficients on the remaining categories are interpreted as the fractional salary deviations from their respective reference categories. Thus, for example, employees in the occupations rated most socially responsible $(O S R>1)$ earned almost 30 percent less than did otherwise similar workers whose occupations were rated between -.5 and .5 . Those in the occupations rated least socially responsible $(O S R<-1)$ earned almost 14 percent more than those in the reference category. The coefficients on the Employer Social Responsibility (ESR) variables were less extreme, but here too the salary differential between categories at the opposite end of the spectrum was both large and statistically significant.

Figure 2 summarizes the estimated compensating differentials for social responsibility reported in Table V. As the figure shows, salaries fall dramatically with increases in social responsibility, even after controlling for sex, curriculum, academic performance, and sector of employment.

Note also in Table $\mathrm{V}$ that the inclusion of the occupational and employer social responsibility variables reduces the estimated wage premium for males still further. It is now just 3.5 percent, a difference that is not statistically significant at conventional levels. The kinds of courses people take influence wages, as do the kinds of jobs they choose. But for this sample, at least, sex appears to have essentially no independent influence on wages.

The estimates of compensating differentials for social responsibility summarized in Table $\mathrm{V}$ and Figure 2 are remarkably large. As noted, they are based on fragmentary measures of occupational and employer social responsibility, and should for this reason be regarded as tentative. 
Table V. The Role of Social Responsibility in Salary Determination

\begin{tabular}{|c|c|c|c|c|c|}
\hline \multicolumn{3}{|l|}{ Variable } & Coefficient & s.e. of Coeff. & $t$-ratio \\
\hline \multicolumn{3}{|l|}{ Constant } & 9.83066 & 0.1311 & 75.0 \\
\hline male & & & 0.035003 & 0.0290 & 1.21 \\
\hline \multicolumn{3}{|l|}{ math } & 0.020190 & 0.0031 & 6.51 \\
\hline \multicolumn{3}{|l|}{ science } & -0.001513 & 0.0027 & -0.558 \\
\hline \multirow{2}{*}{\multicolumn{3}{|c|}{$\begin{array}{l}\text { econ } \\
\text { business }\end{array}$}} & 0.009255 & 0.0046 & 2.03 \\
\hline & & & 0.027121 & 0.0087 & 3.11 \\
\hline \multicolumn{3}{|l|}{ GPA } & -0.012217 & 0.0359 & -0.340 \\
\hline \multicolumn{3}{|l|}{ profit } & 0.039890 & 0.0464 & 0.860 \\
\hline \multirow{2}{*}{\multicolumn{3}{|c|}{$\begin{array}{l}\text { government } \\
\text { nonprofit }\end{array}$}} & 0.00 & - & - \\
\hline & & & -0.282060 & 0.0504 & -5.60 \\
\hline \multicolumn{6}{|c|}{ Occupational Social Responsibility } \\
\hline \multicolumn{2}{|c|}{$O S R<-1$} & & 0.135668 & 0.0526 & 2.58 \\
\hline \multicolumn{2}{|c|}{$-1<O S R<-.5$} & & -0.062383 & 0.0470 & -1.33 \\
\hline \multicolumn{2}{|c|}{$-.5<O S R<.5$} & & 0.00 & - & - \\
\hline \multicolumn{2}{|c|}{$.5<O S R<1$} & & -0.252458 & 0.0820 & -3.08 \\
\hline \multicolumn{2}{|c|}{$O S R>1$} & & -0.294529 & 0.0559 & -5.27 \\
\hline \multicolumn{6}{|c|}{ Employer Social Responsibility } \\
\hline \multicolumn{2}{|c|}{$E S R<-.5$} & & 0.120664 & 0.0492 & 2.45 \\
\hline \multicolumn{2}{|c|}{$-.5<E S R<.5$} & & 0.00 & - & - \\
\hline \multicolumn{2}{|c|}{$E S R>.5$} & & -0.068348 & 0.0843 & -0.810 \\
\hline \multicolumn{2}{|c|}{ Unmeasured OSR } & & -0.080600 & 0.0374 & -2.15 \\
\hline \multicolumn{2}{|c|}{ Unmeasured ESR } & & -0.075870 & 0.0393 & -1.93 \\
\hline Source & Sum of Squares & df & Mean Square & $F$-ratio & \\
\hline Regression & 53.9990 & 16 & 3.375 & 26.1 & \\
\hline Residual & 85.7403 & 663 & 0.129322 & & \\
\hline
\end{tabular}

Notes:

Dependent variable $=$ natural logarithm of salary

$R^{2}=38.6 \%$

$R^{2}$ (adjusted) $=37.2 \%$

$s=0.3596$ with $680-17=663$ degrees of freedom

But as we will see in the sections to follow, they are broadly consistent with evidence from a variety of alternative sources.

\section{Salary Differentials between Corporate and Public Interest Law}

Another source of evidence on the strength of unselfish motives comes in the form of salary differentials between public interest lawyers and corporate lawyers. When the public interest law movement expanded rapidly in the 1960s, the salary differences between public interest lawyers and other attorneys were small, on the order of only a few thousand dollars per year. In the intervening years, however, public interest law salaries have risen only modestly while compensation in other areas of the law has mushroomed sharply. As a result, there is now a large gap between public interest and other legal salaries. Thus, the average starting salary for public interest law- 


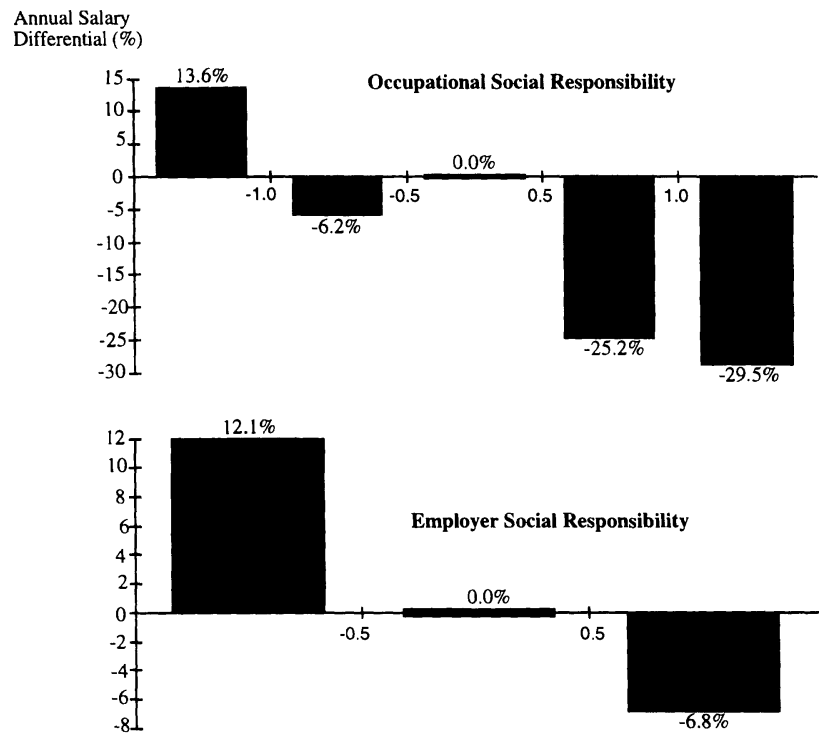

Figure 2. Compensating Salary Differentials for Social Responsibility

yers in 1987 was only $\$ 23,843$, as compared to $\$ 39,847$ for all other lawyers in their first year of private practice $\left[15\right.$, March 27,1989, p. 18]. ${ }^{4}$

The gap between starting salaries for public interest lawyers and first-year associates in private law firms is even larger. Table VI presents 1990 starting salaries for a small sample of institutions in these two categories.

As with our study of salary differences for Cornell graduates, the main problem here, too, is to discover the extent to which differences in law salaries may simply reflect unmeasured differences in productivity. There is some evidence that the lawyers who choose employment in small public interest organizations in isolated locations may indeed have less formidable academic credentials than their counterparts in large urban law firms, but the same can also be said of attorneys who work in small, isolated private law firms. There is apparently a surfeit of highly qualified applicants for each position in well located, highly visible public interest groups, such as the Natural Resources Defense Council and American Civil Liberties Union in New York City. Writing in the National Law Journal, a trade newspaper for the legal profession, Jamienne Studley reported that "... . well-known policy and advocacy organizations are typically deluged with excellent applicants" $[20,16]$. Indeed, such groups are often able to attract law review graduates from the nation's elite law schools, people who could have had their pick from among the choicest entry-level jobs in the legal profession. Even so, the starting salary for an attorney for the New York ACLU in 1990 was only $\$ 28,000$, as compared with an average of $\$ 83,000$ for first-year attorneys in a sample of large New York law firms surveyed by The National Law Journal [15, March 26, 1990, p. s3].

4. See Weisbrod [23], for additional evidence and interpretation of the salary gap between public interest lawyers and those in private practice. One apparent effect of this growing gap has been a steady reduction in the proportion of law graduates accepting employment in the public interest sector. According to surveys done by the National Association for Law Placement, the percentage of law graduates taking public interest jobs fell from 5.9 percent in 1978 to 3.0 percent in 1986. 
Table VI. 1989 Starting Salaries for Private and Public Interest Lawyers

\begin{tabular}{ll}
\hline 1st-Year Public Interest Lawyers & 1st-Year Associates in Private Law Firms \\
\hline American Civil Liberties Union, New York: & Millbank, Tweed, Hadley \& McCoy, New York: \\
$\$ 28,000$ & $\$ 83,000$ \\
Center for Constitutional Rights, New York: & Skadden, Arps, Slate, Meagher \& Flom, New \\
$\$ 29,000$ & York: $\$ 83,000$ \\
People for the American Way, Washington, & Arent, Fox, Kintner, Plotkin \& Kahn, Washing- \\
DC: $\$ 25,000$ & ton, DC: $\$ 66,000+\$ 2,000$ signing bonus \\
Public Citizen Litigation Group, Washing- & Dow, Lohnes \& Albertson, Washington, DC: \\
ton, DC: $\$ 21,000$ & $\$ 67,000$. \\
\hline
\end{tabular}

Source: National Law Journal, March 26, 1990

Published commentary in the legal trade press explicitly acknowledges the link between the lower pay of public interest jobs, on the one hand, and the desire to perform socially beneficial work, on the other. For example, Douglas Phelps, executive director of the Massachusetts Public Interest Research Group and former director of the Public Interest Placement and Career Development Office at Harvard Law School recently wrote that students “. . . get paid sixty thousand dollars for doing what they don't believe in versus fifteen thousand dollars for doing what they do believe in" $[14,27]$. There is also evidence that if the pay gap between public interest law and the rest of the profession were smaller, the demand for public interest positions would be much more intense. A recent fellowship program sponsored by a leading Wall Street law firm that augmented starting salaries in public interest law produced a flood of applicants: "The experience of the new Skadden Fellowships confirms new graduates' intense desire for public interest jobs: More than 600 outstanding beginning lawyers applied for 25 public interest awards that would pay generously for the public sector but well below law firm or even average lawyer starting levels" $[20,16]$.

Private law firms themselves seem to appreciate the strength of the latent demand for a more socially responsible dimension to legal employment, and some are taking concrete steps to incorporate opportunities for public interest work in their own positions. In the spring of 1987, for example, seventeen law firms announced plans to furlough their incoming associates to work for the summer in public interest law agencies "while the firms paid the associates their full salary for ten weeks" $[14,28]$. The firms taking this step are said to view it as an investment in recruitment. According to Sally Hancock, executive director of Public Interest Law Internship, a Chicago-based group that provides summer internships at public interest organizations, "It markets the law firm as one that has an interest in humanity and therefore is humane. It helps them in recruitment" $[20,16]$.

\section{Fees for Expert Witness Testimony}

During the past several decades, there has been a series of legislative hearings concerned with public policy issues related to tobacco smoke. Many of the early hearings focused on whether people who smoke cigarettes are more likely than others to contract various pulmonary and cardiovascular diseases. More recently, the hearings have focused on whether exposure to "second-hand" smoke in the environment is a public health hazard. Throughout all of these hearings, there is a 
common pattern of expert witness testimony. On one side, witnesses associated with the American Cancer Society, the American Heart Association, the American Lung Association, and other public interest groups testify to the effect that tobacco smoke is a significant causal factor in the health problems at issue. On the opposing side, witnesses sponsored by the Tobacco Institute and other industry groups testify to the effect that the health risks associated with tobacco smoke are either unproved or highly exaggerated. Since 1964, when the first Surgeon General's report appeared identifying cigarette smoke as a major public health hazard, there has been a growing perception that advocates of the industry's position in these hearings are morally suspect. By now it seems fair to say that a large percentage of the population shares the perception that witnesses for the public interest groups occupy the moral high ground in the tobacco hearings.

For the purposes of the present study, the question is whether the compensation differentials for the expert witnesses associated with the two sides reflect this perception. In 1967, Senator Daniel Brewster (D, MD) attempted to answer this question by contacting witnesses who had appeared before, or submitted statements to, the Senate Commerce Committee's 1965 hearings on regulating tobacco smoking. Brewster discovered that witnesses favoring cigarette regulation generally appeared as unpaid volunteers. Many pro-industry witnesses refused to discuss their compensation arrangements, but five admitted that they had appeared in return for financial payments from either the industry itself or law firms representing it [3].

In an attempt to discover whether this compensation pattern has persisted, I contacted representatives of various public interest groups who sponsor witnesses before congressional tobacco hearings. These groups reported that, almost without exception, their expert witnesses appear without charge, in many cases even paying their own travel expenses. I have had much greater difficulty obtaining specific information on the fees paid to experts who testify on behalf of the tobacco industry. Indeed, it is fair to characterize these fees as a carefully guarded industry secret. Almost all unofficial sources, however, report that industry groups-most notably the Tobacco Institute-compensate their expert witnesses handsomely. One source, a senior scientific research professional formerly associated with the tobacco industry, reported that the current "official" rate for industry expert witnesses was in the range of $\$ 200$ to $\$ 250$ per hour. This source, who asked not to be identified, also reported that because the industry has an obvious interest in keeping its official witness fees low, the actual rate of compensation in many cases far exceeds the official hourly rate. The difference is achieved in a variety of ways. For instance, witnesses might be paid at the official hourly rate for activities only peripherally related to their testimony-activities such as "keeping up with the literature" or attending professional meetings and conferences. Whatever the total rate of compensation for industry witnesses may be, it is substantial by any standard, certainly far in excess of the payments received by witnesses who appear on behalf of public interest groups (which in most cases, again, are zero).

When questioned, tobacco industry sources make no pretense that the higher fees received by their witnesses are necessitated by superior professional credentials. On the contrary, all available evidence suggests that the volunteer witnesses for the public interest groups are much more professionally distinguished than their tobacco industry counterparts. Most members of the volunteer group are active scientific researchers who hold faculty positions at prestigious universities and medical schools. Most tobacco industry witnesses, by contrast, describe themselves as affiliates of private consulting firms and do not conduct ongoing programs of scientific research. As one former tobacco industry expert witness told me, "At this point, I know of only a few academics who still testify on behalf of the industry. All the others are consultants whose scientific thought process stopped years ago." 


\section{Reservation Pay Premium Survey}

The final component of this study is based on a survey of the employment preferences of a sample of Cornell graduating seniors. In this survey, students were asked to consider six different pairs of hypothetical job descriptions. Within each pair of jobs, pay, working conditions, and the specific tasks involved were described as being essentially the same, but the social responsibility rating of each employer differed (e.g., "write advertisements for the American Cancer Society" vs. "write advertisements for Camel Cigarettes"). ${ }^{5}$ The six pairs of jobs are listed in Table VII.

Subjects were first asked which of the two jobs in each pair they would choose if each paid a salary of $\$ 30,000 / y r$. They were then asked how much higher the salary would have had to be in the job not chosen in order for them to have reversed their decision. As expected, the overwhelming majority of subjects indicated a preference for the jobs in the right column of Table VII. ${ }^{6}$ The proportions choosing these jobs, and the average and median pay premiums required for switching are reported in Table VIII.

The median pay premium for switching jobs was by far the smallest for the sixth pair of jobs - chemist for Dow/chemist for Union Carbide. Two factors may help explain why students perceive any difference at all between these ostensibly equivalent jobs. First, the large volume of negative publicity surrounding the Bhopal disaster in India may have sullied Union Carbide's reputation in the minds of many students. And second, Dow has invested heavily in a recent advertising campaign touting the many socially responsible endeavors in which their employees are engaged. ${ }^{7}$

The largest median reservation pay premium for switching jobs $-\$ 15,000 / \mathrm{yr}$ - obtained for the first pair (ad copywriter for Camel Cigarettes and ad copywriter for The American Cancer Society). Students also reported large reservation pay premiums for the fifth pair of jobs-lawyer for the National Rifle Association and lawyer for the Sierra Club. The median respondent required $\$ 10,000 / \mathrm{yr}$ more in salary to switch from the Sierra Club to the NRA, while the average reservation pay premium reported for the same move was more than $\$ 37,000 / \mathrm{yr}$.

The reservation pay premiums reported by these subjects are large by almost any standard. Of course, it is hard to know whether subjects would really require premiums this large when confronted with an actual opportunity to switch to a less morally attractive, but higher paying, job. It is possible, for example, that people might report high premiums when asked to consider such job changes in the abstract, and yet be willing to switch for significantly smaller amounts

5. The exact wording of the instructions to subjects was as follows:

Several pairs of jobs are described on the list below. All of these jobs offer a starting salary of $\$ 30,000 /$ year. The jobs in each pair are located in the same city, and both involve working the same number of hours each week. The actual tasks you perform in each job are essentially the same, as are all relevant fringe benefits (pensions, paid vacations, insurance, etc.). The only real difference between the jobs in each pair involves the nature of the employer's line of business. In one of the blank spaces provided next to each job, check the member of each pair of jobs that you would accept if you had to choose one or the other. Then in the blank space below the job you did not choose, write the minimum annual salary required for you to switch your job choice. To illustrate, suppose that in the first pair of jobs you choose to work for The American Cancer Society when both jobs pay $\$ 30,000 /$ year. You should then use the blank space below the Camel Cigarettes job to indicate how high its salary would have to be for you to switch. For example, if you say $\$ 40,000$, that means that if Camel paid $\$ 39,999$ or less you would still choose The American Cancer Society, but that for $\$ 40,000$ or more you would choose Camel.

6. On the actual survey form completed by subjects, the more attractive job for a given pair sometimes appeared on the right, sometimes on the left.

7. It is interesting to note that in the late 1960 s and early 1970 s, the perceptions of these two companies was likely the reverse. Dow was at the time under heavy criticism for its manufacture of napalm, which was being dropped by American bombers on the villages of Vietnam. 
Table VII. Six Hypothetical Career Decisions

Ad copywriter for Camel Cigarettes

Accountant for a large petrochemical company

Language teacher for the CIA

Recruiter for Exxon

Lawyer for the National Rifle Association

Chemist for Union Carbide
Ad copywriter for the American Cancer Society

Accountant for a large art museum

Language teacher for a local high school

Recruiter for the Peace Corps

Lawyer for the Sierra Club

Chemist for Dow Chemical

Table VIII. Reservation Pay Premiums for Sacrificing the Moral High Ground

\begin{tabular}{lccc}
\hline & Percent Choosing & $\begin{array}{c}\text { Median Pay Premium } \\
\text { for Switching }\end{array}$ & $\begin{array}{c}\text { Average Pay Premium } \\
\text { for Switching }\end{array}$ \\
\hline American Cancer Society & 88.2 & $\$ 15,000 / \mathrm{yr}$ & $\$ 24,333 / \mathrm{yr}$ \\
Art museum & 79.4 & $\$ 5,000 / \mathrm{yr}$ & $\$ 14,185 / \mathrm{yr}$ \\
High school & 82.4 & $\$ 8,000 / \mathrm{yr}$ & $\$ 18,679 / \mathrm{yr}$ \\
Peace Corps & 79.4 & $\$ 5,000 / \mathrm{yr}$ & $\$ 13,037 / \mathrm{yr}$ \\
Sierra Club & 94.1 & $\$ 10,000 / \mathrm{yr}$ & $\$ 37,129 / \mathrm{yr}$ \\
Dow Chemical & 79.4 & $\$ 2,000 / \mathrm{yr}$ & $\$ 11,796 / \mathrm{yr}$ \\
\hline
\end{tabular}

*Excludes one response of $\$ 1,000,000,000,000 / \mathrm{yr}$.

when confronted with the reality of personal budget problems. Bear in mind, though, that we saw compensating differentials on an even larger scale in the case of public interest lawyers and their counterparts in private law firms. And even if the actual reservation premiums were only one tenth as large as the ones reported by our survey respondents, they would still constitute a highly significant feature of the contemporary labor market.

The survey results reported in this section help supplement the earlier findings in two important ways. First, because the sample of students was randomly chosen, the problem of unobserved differences in individual productivity is no longer an issue. (Recall that the earlier Cornell survey suffers from this problem because it consists of people who have already segregated themselves into different categories of employment.) A second problem with the earlier Cornell survey involves the effect of differing attitudes about social responsibility. If people's feelings about this issue differ substantially, then the observed wage premium for socially irresponsible tasks will tend to understate the compensation required by the average person to perform such tasks. In the limiting case, if there were sufficiently many people who didn't care about whether they performed socially responsible tasks, we would observe no wage premium at all for the performance of disapproved tasks. The fact the survey reported in this section asks for the reservation wages of a random sample thus helps shed additional light on the population distribution of valuations for socially responsible tasks.

\section{Implications for Business Behavior}

Suppose we accept, for the sake of discussion, that there are significant compensating salary differentials for social responsibility on the job. This relationship has important implications for the behavior of firms with respect to a variety of moral and ethical issues. In particular, it challenges the widely held view that the social obligation of a private firm extends no further than to obey the laws of the society in which it operates [8]. The seemingly compelling argument in support 
of this view is that any business that attempts to exceed this standard is destined to be driven out of business by competitors. This argument fails, however, if there are significant compensating salary differentials for social responsibility in the workplace, for such differentials may often enable firms to withstand the higher costs that would otherwise be associated with acting in a socially responsible manner.

\section{Concluding Remarks}

In this paper, I have examined the labor market for evidence relevant to the claim that the economic choices of many people are significantly guided by unselfish motives. Earlier studies provided qualitative support for this claim on the basis of survey evidence. One author found that college students listed "helping others" as one of their most important career goals. Another found that executives believed that their firms' ethical posture had a significant impact on their ability to recruit and retain desirable employees. And a survey of executives in the management information systems field found a significant negative correlation between job satisfaction and the extent to which respondents felt that other executives in their firm engage in unethical behavior.

We then saw a variety of evidence of a strong negative correlation between annual earnings, on the one hand, and the degree to which an employee's employer and occupation are viewed as being socially responsible, on the other. The most systematic of this evidence came from a survey of graduates of Cornell University's College of Arts and Sciences. The same pattern was observed in comparisons of the fees paid to expert witnesses who testify on behalf of the tobacco industry and their counterparts who testify for the American Heart Association and other public interest groups. We also saw dramatic pay differences between public interest lawyers and those employed in other segments of the legal profession. And we saw survey evidence from a sample of graduating seniors who reported that they would require large premiums before being willing to switch to a less socially responsible employer.

Each of these pieces of evidence, taken individually, is subject to alternative interpretations. When taken as a whole, however, the evidence paints a picture that is strongly consistent with the claim that unselfish motives figure prominently in economic behavior. It seems fair to conclude that the burden of proof now properly lies on those who claim that economists may safely neglect unselfish motives.

\section{References}

1. Ashenfelter, Orley and J. Mooney, "Graduate Education, Ability, and Earnings." Review of Economics and Statistics, February 1968.

2. Baumhart, Raymond. Ethics in Business. New York: Holt, Rinehart, and Winston, 1968.

3. Business Week. "Should Paid Witnesses Say So?" September 9, 1967.

4. Cellucci, Anthony and David De Vries. Measuring Managerial Satisfaction: A Manual for the MJSQ, Technical Report II. Center for Creative Literature, 1978.

5. Frank, Robert H. Passions Within Reason: The Strategic Role of the Emotions. New York: W. W. Norton, 1988.

6. — Thomas Gilovich, and Dennis Regan, "Does Studying Economics Inhibit Cooperation?" Journal of Economic Perspectives, Spring, 1993, 159-171.

7. — , "Do Economists Make Bad Citizens?” Journal of Economic Perspectives? Spring 1996.

8. Friedman, Milton, “The Social Responsibility of Business Is to Increase its Profits." New York Times Magazine, September 13, 1970.

9. Handy, Femida. "Trust Within the Nonprofit: Wage Differentials as a Means of Resolving the Principal-Agent Problem.” Unpublished paper, York University. 
10. Hauser, Robert and Thomas Daymont, "Schooling, Ability, and Earnings: Cross-Sectional Findings 8 to 14 Years After High School Graduation.” Sociology of Education, July 1977.

11. Linden, Paula S., Gail G. Penshel, and Jamienne S. Studley, "What Happened to the Class of '87?" National Law Journal, March 27, 1989, 1.

12. Mansbridge, Jane. Beyond Self Interest. Chicago: University of Chicago Press, 1990.

13. Mervis, P. H. and E. J. Hackett, "Work and Workforce Characteristics in the Nonprofit Sector," Monthly Labor Review, April 1983, 3-12.

14. Miller, Lynn, “Debt Trap.” Student Lawyer, September, 1987, 22-29.

15. National Law Journal, various issues.

$\rightarrow$ Preston, Anne E., “The Nonprofit Worker in a For-Profit World.” Journal of Labor Economics, 7(4), 1989, 438-63.

17. Rosenberg, Morris. Occupations and Values. Glencoe, Ill.: The Free Press, 1957.

18. Shackett, J. and J. M. Trapani, "Earnings Differentials and Market Structure." The Journal of Human Resources, 12(4), 1987, 518-31.

19. Sharp, L. M. Education and Employment: The Early Years of College Graduates. Baltimore: Johns Hopkins University Press, 1970.

20. Studley, Jamienne S., "Financial Sacrifice Outside the Private Sector." National Law Journal, March 27, 1989.

21. Tullock, Gordon. The Vote Motive. London: Institute for Economics Affairs, 1976.

$\rightarrow$ Vitell, Scott J. and D. L. Davis, "The Relationship Between Ethics and Job Satisfaction: An Empirical Investigation.” Journal of Business Ethics, 9, 1990, 489-94.

$\rightarrow$ Weisbrod, Burton, "Nonprofit and Proprietary Sector Behaviour: Wage Differentials Among Lawyers." Journal of Labor Economics, 1, 1983, 246-63.

24. Yezer, Anthony, Robert Goldfarb, and Paul Poppen, "Does Studying Economics Inhibit Cooperation? Watch What We Do, Not What We Say." Journal of Economic Perspectives, Spring 1996. 